\title{
95 the new woman and the dusky strand': the place of feminism and women's literature in early Jamaican nationalism
}

\author{
Leah Rosenberg
}

\section{abstract}

This essay analyzes the prominent role played by first wave feminism and by women writers between 1898-1903 as the Jamaica Times articulated a broad-based, middle class nationalism and launched a campaign to establish a Jamaican national literature. Largely overlooked, this archival material is significant because it suggests a subtle yet significant modification of anglophone Caribbean feminist, literary and nationalist historiography: first wave feminism was not introduced to Jamaica exclusively through black nationalist organizations in the late nineteenth and early twentieth century, but rather, it emerged in a broader phenomenon of respectable, middle class nationalism, encompassing the overlapping projects of Jamaican nationalism and Pan Africanism. Thus, it becomes clear that first wave feminism, including white women writers, played a key but brief role in the formation of the middle class nationalism that would later dominate Jamaica's transition to independence. During the first five years of publication of the Jamaica Times, women wrote a significant proportion of the short stories published. However, they became marginalized as black folk culture became the defining symbol of national authenticity. The marginalization of middle class women writers reflects a broader pattern. In adopting first wave feminism from Britain and the United States, Jamaican nationalists reproduced colonial race and class dynamics that established an unbridgeable divide between middle class women, who served as 'ladies bountiful,' and the usually darker-skinned compatriots to whom they ministered. This class division continued to limit feminist activism in Jamaica throughout the first and second waves.

\section{keywords}

feminism; Jamaica; nationalism; literature; respectability; class 


\section{introduction}

First-wave feminism was introduced to Jamaica in the late nineteenth century. The country was in fundamental transition. US power was ascending; British power was receding. Large-scale migration and urbanization brought thousands of Jamaicans to Latin America and within Jamaica to Kingston. In the face of these new realities, a broad-based middle-class nationalism emerged and made feminism central to its claims for economic opportunity and political power even to its campaign for a national literature by and about Jamaicans.

The national movement comprised the social groups between the elite (the planter and merchant classes) and the labouring masses (black peasants and indentured Indian and Chinese labourers). Of these groups, Afro-Jamaican teachers and ministers were dominant, but this diverse middle class also included artisans, civil servants, small-scale business people and professionals. Though predominantly composed of light-skinned or brown Jamaicans, this group was at its root class-based. Thus, it included Jewish, white and black Jamaicans, such as author Claude McKay and his brother Uriah Theodore McKay, a teacher and civic leader.

Largely excluded from government, middle-class leaders founded a wide range of institutions to achieve their interests. Not only did many of these organizations espouse feminist principles, but they also gave women prominent roles as members and leaders, so much so in fact that women might be described as the backbone of early Jamaican nationalism. These organizations included political institutions and newspapers, such as Robert Love's Pan-Africanist newspaper, the Jamaica Advocate, and his party, the People's Convention; labour organizations, such as the Jamaica Union of Teachers (JUT); and cultural clubs like the Jamaica Local Literary Association (JLLA) and the James Hill Literary Association (Bryan, 1991: 224). Women were particularly active as literary writers and in uplift organizations, such as the Moravian Upward and Onward Society, and the Anglican Mother's Union (Bryan, 1991: 165). Known as the teachers' paper, the Jamaica Times played an especially important role in this national movement by presenting its interests, recording the activities of its various institutions, and launching a movement to establish Jamaican literature. The paper became a nexus for early nationalism and is therefore the primary source of data for this article.

Because the middle classes were systematically denied financial capital and political rights, they derived power from the cultural capital of their respectability which comprised 'a value complex emphasizing the cultivation of education, thrift, industry ... moderate Christian living, community uplift, the constitution of family through legal marriage and related gendered expectations, and leadership by the educated middle classes' (Thomas, 2004: 5-6). Based in

patriarchal marriage and a class hierarchy, such respectability had strong 
1 I refer here to the ideal invoked by nationalists. In practice, the

Jamaican public had nuanced expectations of respectability for different classes (Altink, 2003). implications for middle-class women and feminism - and for class relations. Christian marriage imposed domestic womanhood and financial dependence on women; yet it was also a privilege of the middle class and elite because marriage required a family to own a home and support a wife as homemaker. ${ }^{1}$ At the same time, nationalists called for class and racial justice and embraced peasant culture and African heritage as a means of producing a national consciousness and culture. But ultimately, respectable nationalists saw themselves as superior to the largely uneducated, unwed working classes, and this sense of superiority fostered a class division particularly prominent between middle and working class women.

With the exception of the Pan African organizations, historians have generally not considered these activists and intellectuals to be nationalists. However, I identify them as nationalists because their primary objectives were the promotion of a distinct Jamaican culture and consciousness, and the political and economic empowerment of Jamaicans. Moreover, many within the movement did espouse a racial consciousness evidenced in the Jamaica Times' extensive coverage of racial oppression and the achievements of black artists and political leaders, such as Booker T. Washington. Indeed their middle-class status and respectability identify them as an earlier generation of the middle-class nationalists, who took a leadership role in the working-class rebellion of 1938 and led Jamaica into independence in 1962 (Thomas, 2004: 51).

The exclusion of this early nationalism from historiography has distorted our understanding of the history of feminism and women's writing in Jamaica, by promoting the impression that feminism was the sole project of Pan Africanism and not part of much broader movement. As a result, both the existence of Jamaican women writers at the turn of the century and their self-conscious participation in building Jamaican nationalism have been obscured. My objective in this article is thus two-fold: to extend Jamaican historiography to include this early nationalism and to illuminate the significance of the feminism it promoted and the women writers who contributed to it. In so doing, I build on the work of anthropologist Deborah Thomas who has made the case that black Jamaican civic leaders in the 1880 s espoused a middle-class respectable nationalism that developed into the multi-racial middle-class nationalism that dominated in 1960s. I look also to the strong parallels with nationalism in nineteenth-century Bengal, which like early Jamaican nationalism, promulgated a feminist ideology and was at first overlooked by historians. In the case of Bengali nationalism, however, subaltern historians have successfully expanded the historical tradition to include early nationalism (Chatterjee, 1993). Moreover, feminist historian, Mrinalini Sinha, has made a strong case that early Indian nationalism gave middle-class women a certain amount of agency despite its patriarchal ideology but that it also implicated them in a divisive class and 
ethnic politics that had far-reaching consequences long into independence (Sinha, 1994, 2000).

The body of this essay is an examination of the feminist ideology expressed and the women's literature published in the Jamaica Times from 1898 to 1903, the first five years of the paper's publication and the period of the short story contest, which launched a campaign to promote Jamaican literature. It provides evidence for my contention that at the turn of the twentieth century, middleclass Jamaican women found themselves in a position similar to that of women in early Indian nationalism. They were constrained by its patriarchal ideology but they also had the ability to diverge from and critique it. Further, much like their Indian counterparts, Jamaican middle-class women became implicated in divisive politics; by embodying a model of feminine virtue, they fostered a class and colour hierarchy that would influence Jamaican feminism and nationalism into the period of independence.

\section{first-wave feminism and early Jamaican nationalism}

Within this early nationalist movement, Jamaican middle-class women were symbols of Jamaican modernity; it was believed that their uplift work would raise the rest of Jamaica and the race into modernity. 'Train the women of a country into ideals of nobility and usefulness', wrote the editor Thomas MacDermot and 'you add immensely to that country's real civilization and prosperity' (Jamaica Times, 1 May 1909: 10). Robert Love shared MacDermot's vision, stating that: 'The Jamaica Advocate always held that the best means of raising a people is by striving to uplift the women of that race' (Jamaica Advocate, 28 December 1901, cited in French and Honor Ford-Smith, 1986: 208).

To this end, leaders such as Love and MacDermot advocated principles of firstwave British feminism: women's suffrage, women's professional education and women's work in social reform. Love's party, the People's Convention, provided women a public forum as did uplift societies and cultural clubs. Both sought significant improvements for Jamaican women. MacDermot, for example, demanded equal pay for women workers and more positions for women teachers (Jamaica Times 14 December 1901: 9; 1 February 1903: 14). He heralded suffrage and professional education for respectable women, reminding his readers that women had the right to vote in New Zealand, Australia, Denmark, Norway, Massachusetts and Wyoming (Jamaica Times 7 March 1903: 5; 10 April 1909: 10). MacDermot stressed the significance of women intellectuals and artists, featuring numerous articles on foreign celebrities such as the British travel writer Mary Kingsley and American poet Ella Wheeler Wilcox among others (Jamaica Times, 23 June 1900: 1; 25 April 1903: 1). He was no less assiduous in 
2 In literature, see Vic Reid's New Day (1949) for its positing of the Morant Bay Rebellion as a precursor that built to promoting Jamaican women. The Jamaica Times consistently and prominently published Jamaican women's short stories, poetry and letters.

However, as they gained access to the public sphere, Jamaican middle-class women were inscribed into the divisive class politics of nationalism. Reflecting the role of feminists as social workers in Britain, middle-class Jamaican women were allotted the role of social worker, in the words of French and Ford-Smith, the 'lady bountiful', who, selfless and chaste, brought charity and reform to the working and peasant classes (1986: 168-198). In so doing, they performed the role of civilizing colonizers to their often darker-skinned compatriots. This divide was reinforced through the Jamaica Times' many articles on the good deeds of the Ladies Self Help Society and other charitable organizations; frequent coverage of working class and peasant women as dangerous perpetrators and tragic victims of crime; comic court reports that ridiculed working-class marriage and domestic life; and tourist essays that rendered peasant religion quaint and exotic.

Yet, despite these stereotypes that reinforced class divides, some middle-class women were able to challenge these divisive imperial elements of nationalism. For instance, in a speech on the Home Life Committee of the Christian Endeavour Society, Mrs S.R. Brathwaite advocated housing reform and the dissemination of Jamaican literature to alleviate the material and psychological effects of colonialism and racism. Working-class Jamaican women needed material assistance; their alleged immorality resulted not from inherent racial inferiority but from material deprivation and men's irresponsibility (Jamaica Times 1 December 1900: 14). Brathwaite buried her observations in talk of prayer and marriage; nevertheless, she refuted the imperial core of domestic ideology that Jamaican nationalism had embraced, namely the assertion that black and working-class women were by nature less moral than their lighter-skinned and wealthier sisters.

Early nationalism, I argue, facilitated Jamaican middle-class women's access to the public sphere and made feminism central to Jamaican nationalism but first- and second-wave feminism in Jamaica were undermined by the patriarchal nature of nationalism and the imperial nature of the feminism it adopted. Further, the feminism expressed by the Jamaica Times at the turn of the century indicates a broad acceptance of feminism in Jamaica at least 30 years earlier than feminist scholarship has suggested. It also challenges us to rethink the dominant historical narratives of Jamaican nationalism and national literature. Jamaican nationalism has traditionally been defined as the anti-colonial nationalism of the mid-twentieth century, which is often seen as the culmination of a teleological series of slave, peasant, and worker rebellions. ${ }^{2}$ These in turn have been identified with male leaders, who comprise six of Jamaica's seven official national heroes: Sam Sharpe of Jamaica's largest slave rebellion, the Baptist War (1831-2); Paul Bogle and George William Gordon of the Morant Bay Rebellion; Alexander Bustamante and Norman Manley of the 1938 labour 
rebellion; and Marcus Garvey, founder of the Universal Negro Improvement Association (UNIA).

Anglophone Caribbean literary history has been shaped by a similarly teleological, nationalist, and male-dominated narrative. The tradition has been viewed as beginning in the 1950s with the emergence of an anti-colonial and predominantly male generation of authors - V.S. Naipaul, George Lamming, Sam Selvon - who emigrated to London and brought the region's literature international acclaim (Donnell, 2006: 11). Their work was seen as the culmination of a series of male precursors whose writings depicted workers or peasants, such as Thomas MacDermot, Herbert de Lisser, Claude McKay and George Campbell. This trajectory has privileged Afro-Caribbean, male and anti-colonial writers and contributed to the perception that anglophone Caribbean women began to write in the 1970s - a phenomenon derived from the male generation of the 1950s. In the case of Jamaica, these dominant political and literary histories erased from public memory at least 50 years of literary production and the emergence of the multiracial, middle-class nationalism that would lead the country into independence. In so doing, these dominant narratives also silenced the contributions of women and feminism to early Jamaican nationalism and literature, thus contributing to the perception that feminism was alien and at odds with Jamaican nationalism.

\section{the first wave in Jamaican feminist historiography}

Early feminist scholars of the Caribbean challenged this male-dominated historiography by making visible the women leaders and participants in slave resistance, the labour movement and the rise of nationalism (Mathurin, 1975; Reddock, 1988a). In the 1980s, they were particularly concerned with the history of feminism and women's movements (French and Ford-Smith, 1986; Vassell, 1993; Reddock, 1994). Feminist scholars sought to address the perception that 'feminism [was] a white middle-class import introduced into the Caribbean in the nineteen sixties and seventies [and] that to Caribbean women it [was] irrelevant and to Caribbean society divisive' (Ford-Smith, 1986: 1). They did so by asserting that the first Caribbean feminists were 'black nationalists in the late 19th century and early 20th century' (French and Ford-Smith, 1986: 199), thereby incorporating Caribbean feminism into the dominant narrative of anti-colonial resistance. In the process, they established a widely accepted genealogy of firstwave Jamaican feminism that, aside from adding women, did not challenge the existing teleological historiography (French and Ford-Smith, 1986; Reddock, 1988b, 1990). The history begins with the Lady Musgrave Self-help Society, an organization formed in 1879 by the Governor's wife to assist white and other elite women in earning money. It was presented as part of a women's movement on the grounds that it asserted women's right to work outside the home (French and self-government in

1944. In historical studies, see Philip Sherlock and Hazel Bennett, The Story of the Jamaican People (1998). 
3 More recently, Veronica Gregg has offered a much more critical view (Gregg, 2005: 42).
Ford-Smith, 1986: 150; Reddock, 1990: 62-63). ${ }^{3}$ Robert Love's Pan African movement constitutes the next development in this chronology of Jamaican feminism because the movement promoted black women as leaders and promulgated first-wave feminist ideology (Reddock, 1990: 74-75). As secretary for the Pan African Association, Catherine McKenzie delivered a number of speeches on women's rights, one of which is extensively analysed by French and Ford-Smith (1986: 203-207) and anthologized (Vassell, 1993: 5-7; Gregg, 2005: 99-103). The narrative then skips 17 years to 1918 when the Jamaica's Women's Social Service Club (WSSC) was founded, ostensibly marking the entrance of middle-class Jamaican women into social work (French and Ford-Smith, 1986: 174-181; Reddock, 1990: 65).

The incorporation of feminism into the narrative of black nationalism gained depth and nuance with Amy Bailey and Una Marson, public intellectuals and feminist 'ladies bountiful' active in the national awakening of the 1930s. Both contributed essays on feminism to the nationalist weekly, Public Opinion, in the late 1930s, and together they founded the Jamaican Save the Children Fund (Gregg, 2005: 141-116). With other women members of the Jamaica Union of Teachers, Bailey founded the Women's Liberal Club in 1937 which promoted women's entrance into politics and campaigned to break the colour bar that kept black women from better paying jobs (French and Ford-Smith, 1986: 249). Marson combined social work, black nationalism and feminist activism with a strong commitment to writing and promoting Caribbean literature. She helped to found a mutual aid society for Jamaican secretaries and its journal, the Cosmopolitan. She served as secretary to Haile Selassie during his mission to the League of Nations. She wrote poetry, plays and short fiction; and she promoted Caribbean literature as the founder of a number of cultural institutions, most significantly the BBC programme, Caribbean Voices, which helped to launch the careers of many West Indian authors of the 1950s. Yet even as French and Ford-Smith celebrated Marson and Bailey as founding mothers of Jamaican feminism, they highlighted their limitations. Marson and Bailey were presented as elitists. Bailey favoured birth control to reduce the numbers of working-class people she feared would swallow up Jamaica's respectable classes (French and Ford-Smith, 1986: 250, 257). Marson enticed feminists with her playful parodies of marriage and her portrayal of independent women, but she also disappointed them with hopelessly unrealistic and patriarchal happy-marriage endings (Ford-Smith, 1986: 19-20).

In the 1990s, the theoretical ground shifted as scholars focused on the contingent, contested, and contradictory nature of colonialism and of the relation between metropole and colony (Cooper and Stoler, 1997). Rather than criticizing earlier feminists for lacking radicalism or inserting them into a teleological narrative of black nationalism, scholars now examined the emergence of feminism through a complex interplay of colonial and anti- 
colonial forces. In this context, Gita Sen and Peggy Antrobus described feminism as emerging from broader nationalist and 'social reform movements in the colonized countries' in the nineteenth century (2006: 142). Rhoda Reddock and Patricia Mohammed explicitly included the Anglophone Caribbean in this pattern (Reddock, 1990: 74; Mohammed, 1998: 13-16). Women and feminism were introduced to early nationalist movements in India, Africa and the Caribbean, scholars explained, because colonized male intellectuals saw the principles of first-wave feminism as important to their own struggle for power and legitimacy. The status of women was widely viewed in European discourse as an index of a people's level of civilization. As a corollary, European domestic womanhood was presented as the pinnacle of European modern achievement. Britain had defined its colonized subjects as inferior and in need of colonial rule by pointing to the ways colonized cultures (mis)treated their women: for example, Indians married off their daughters as young children, and Africans practiced polygamy. In the Caribbean, black working women perverted the modern gender order by performing hard labour appropriate only for men. Their ostensible economic and sexual independence attested to the failure of Afro-Caribbean men to govern even their families. Thus, in an effort 'to improve the image of their civilization in the eyes of colonial rulers', Reddock explains, Caribbean and other colonized intellectuals adopted British feminist reforms (1990: 63).

However, in adopting British feminism, early nationalists inherited its hierarchical class and imperial structure. British feminists worked to improve and uplift the nation's less privileged classes in regard to labour conditions, morality, education and health. In the colonies, they were 'Empire builders' lifting up colonial subjects. British feminism was simultaneously nationalist and imperialist because feminists claimed citizenship on the basis of these contributions to the nation and its empire (Rendell, 2004: 40). Moreover, British feminists' claim to citizenship rested on a construction of British women as not only superior but also antithetical to colonized women. As Antoinette Burton has emphasized, British feminists 'cultivated the civilizing responsibility and its attendant imperial identity as their own modern womanly and secular burden' (1994: 13).

Neither the first-wave feminist genealogy of the 1980s nor the reconceptualization of early feminism in the 1990s included the early Jamaican feminism recorded in the Jamaica Times. Rather, the new conceptual framework was superimposed on the dominant genealogy of feminism outlined above. While it accurately describes feminism in the Pan African movement and the UNIA, this superimposition obscures the fact that feminism was central also to the broader multiracial nationalism that emerged in the late nineteenth century and became dominant in Jamaica from the 1940s to the 1980s. This broader nationalism, as represented in the Jamaica Times, established women's literature at the core of the nationalist project; Pan African organizations did not. Pan-Africanism of the turn of the century probably did influence Bailey and Marson indirectly. ${ }^{4}$ But the 
Africanism of the London League of Coloured Peoples may have had more direct influence as Marson and Bailey knew its work and its leader, Harold Moody (JarrettMacaulay, 1998: 52-55). influence of the broader movement centred in the Jamaica Times was probably more direct and therefore stronger. Love's Pan African movement ended in the early 1900s when Bailey and Marson were children. By contrast, the Jamaica Times continued publication into the 1960s. As mentioned earlier, the core readership of this publication was the Jamaican Union of Teachers, and not only was Bailey's father a teacher, but Bailey herself was a leader in the JUT. Marson's father had also been a teacher before becoming a minister, and her sister Edith was a headmistress and JUT member (Jarrett-Macaulay, 1998: 27). Marson and Bailey may not have known the early women writers or 'ladies bountiful', but the fact that they took for granted that feminism and women's literature belonged in Jamaican nationalism was an inheritance from that earlier generation.

In the past decade scholars have taken further steps in rethinking the history of Caribbean nationalism and literature that now make it possible to recognize the significance of feminism in early Jamaican nationalism. Deborah Thomas has identified a group of black Jamaican intellectuals in the 1880s as nationalists. Their social position, respectability and class politics closely resemble those of intellectuals surrounding the Jamaica Times at the turn of the century. I therefore have presented that broad-based nationalism as closely related to, and expanding the constituency of, the earlier group (Thomas, 2004: 29-57). Literary scholars are likewise dismantling the anti-colonial literary canon. Belinda Edmondson has established that far from anti-colonial aesthetic revolutionaries, Caribbean writers of the 1950s were shaped by Victorian models of literature and the writer (1999: 5). Scholars have critiqued the maledominated nationalist literary canon and provided a literary history dating back to the early nineteenth century (Donnell, 2006: 11; Rosenberg, 2007: 3-6). Of particular significance is Evelyn 0'Callaghan's study of white women's writing between 1804 and 1939 which contests the dominant view that West Indian women's writing began in earnest in the 1970s (2004: 1-8). But even 0'Callaghan and Donnell, the few scholars to have read the work of early Jamaican women writers like Clarine Stephenson, have not presented them as part of a nationalist project because the nationalism they participated in has not yet been made visible.

To bring the women of the Jamaica Times fully into history we need to integrate these developments in nationalist, feminist, and literary historiography and to do this, I propose building on the work of subaltern and feminist historians of India because they have successfully expanded the conception of Indian nationalism and clarified the role of feminism within it. While the traditional political history of Indian nationalism features the founding of the Indian National Congress in 1885 and the demand for total independence in 1929, Partha Chatterjee has established that nationalism dates back to the first half of the nineteenth century when a political discourse centred on women and social reform began to 
revolutionize the Bengali intellectual community. By the 1820 s and 1830 s, urban middle-class Hindus in Calcutta were articulating an Indian nationalism within the framework of the British Empire much as middle-class Jamaicans were in the 1890s (Chatterjee, 1993: 6). Like their Jamaican counterparts, Indian nationalists made women's rights and literature prominent in their debates and publications (Bhattachararya, 1980: 1-18). Like their Jamaican counterparts, they gave women access to the public sphere while at the same time significantly constraining their participation within a patriarchal ideology. While Chatterjee emphasizes these patriarchal constraints, Mrinalini Sinha stresses instead that Indian nationalism facilitated women's activism in the public sphere and made 'the reform of women's present position and the creation of the new woman ... a legitimate nationalist preoccupation' (Sinha, 1994: 2, 7). In the process, nationalism implicated women in the divisive communalism that early nationalism reinforced (Sinha, 2000: 1081).

In the remainder of this essay, I analyse women's short stories published in the Jamaica Times between 1898 and 1903 to illustrate that Jamaican nationalism at the turn of the century followed a similar pattern. Feminism became a central element of nationalism, which offered women access to the public sphere - even the opportunity to challenge nationalist ideology. At the same time, the patriarchal ideology of nationalism constrained their thought and action while the movement's embrace of Western modernity and British feminism implicated them also in a racial and class hierarchy that reproduced colonial relations and inequities in postcolonial Jamaica.

\section{women writers and the formation of Jamaican national literature}

Women won roughly one third of the weekly prizes during the Jamaica Times short story contest (1898-1903). The contest awarded prizes to romances, historical fiction, as well as comic and tragic sketches of peasants and workers. Women wrote primarily romances about middle-class women which celebrated the ideal of middle-class domestic womanhood promoted by national leaders. However, they also challenged that model. Their work reveals much about the shaping of Jamaican literature at the outset of the tradition.

Nearly all women's stories featured wives or daughters of clerks, surveyors, teachers or struggling planters. These heroines represented the constituency of the nationalist movement and the ideal of womanhood it propounded. In Annie $\varepsilon$. Cork's 'Such is Life in the Tropics', the unassuming Dora represents this ideal and is contrasted with her elder sister, Miss Bessie, who resembles British stereotypes of the female aristocracy and plantocracy. Bessie is vain, arrogant and not quite proper. She overlooks the young creole clerks and planters, accepting the hand of 
an English Captain without first asking her father's permission. While all men court her sister, Dora 'went in and out, looked after everyone, comforted the boys to the best of her ability, and was a general heal-all' but 'nobody worshipped her at all!' (Cork, 1899: 13). After Bessie's marriage to the wealthy English captain, one of her rejected suitors, a middle-class man, realizes that little Dora is 'worth a dozen of Bessie', thus vindicating the domestic middle-class woman.

However, women's short stories also criticized this ideal. Florrie Somerset's 'Two Girls in the Valley', for instance, foregrounds the vulnerability of middle-class women. The tale begins when a mother advises her daughter Maria to please a visiting bachelor. 'You are a poor girl', she explains, 'and must do all that lies in your power to get married, for what will become of you when I die if you are not?' (Somerset, 1899: 13). However, despite Maria's best efforts, Arthur, the bachelor, falls in love with Minnie Clarkeston, Maria's neighbour. Already enamoured by her beauty, Arthur is horrified to discover that Minnie is being forced to marry Mr Helwig, a much older and wealthy man, whom she despises. Arthur determines to rescue her by marrying her himself. The story ends happily. Minnie marries Arthur, leaving Mr Helwig free for Maria, who being 'very practical' accepts him. Despite the happy ending, the story reveals that a Jamaican society that insists on marriage for middle-class women and fails to provide career opportunities places women at risk of poverty and coercion.

In contrast to Somerset's protagonists, Nita, Winifred Winn-Smith's heroine in 'Moonlight Murder' fails to marry and is trapped as a 'bond slave'. The story opens as Nita's uncle, an overseer, awaits his son who is carrying his workers' wages. Only his horse arrives; the son has been ambushed and murdered by Nita's beloved. The murderer cum fiancé rushes from the murder scene to the innocent Nita but falls to his death just as he reaches her. Nita plays no part in the story's action but is presented as the story's tragic victim. The narrator reveals only her life circumstances and inner thoughts not those of any other characters. When Nita finds her fallen lover, the narrator addresses her: 'Ah! No little girl, those ears are deaf to you now. Never again will those eyes lighten at your coming. ... You must learn the "sad, sad, lesson of loving" .... You must return to your old monotonous life, and live it - without him' (Winn-Smith, 1898: 13). The story ends with Nita longing to die. If read as an allegory of respectable nationalism, 'Midnight Murder' suggests that men may play the leading roles in the nation's story, but the real tragedy is that of middle-class women, who are destined to become 'bond slaves' to men in their own families.

Women writers also challenged the constraints of domesticity. The heroine of Una Jeffrey-Smith's 'Foiled' is the daughter of a cash-strapped teacher, who is sent to borrow money from her wealthy uncle so that her father can keep his land. She must return along a deserted road by night. As she sets out, Gladys ridicules her wealthy aunt: 'The idea of her giving me crochet patterns to occupy my mind. If 
she had for one week the cares that I have month after month to occupy her mind' (Jeffrey-Smith, 1899: 13). This quip criticizes women's organizations featured in the Jamaica Times that famously taught needlework as a solution for the material needs of Jamaica's working women.

Ironically, the crocheting saves Gladys, but only because she literally throws it away. Gladys is ambushed at gun point as she carries the money to save her family's land. Rather than give her assailant the money, she steals his gun and shoots him, only to find that the 'coward' has left it unloaded. When he finally overpowers her, she agrees to give him the money. Throwing the packet as far she can, she gallops off - only later to discover that she has given him the crochet patterns. However, as much as Gladys may prove herself to be a model woman, dedicated to her family, her virtues are hardly restricted to the home. The castoff patterns signify the casting off of domesticity.

Clarine Small's 'In the Queen's Name' reworks the ambush plot yet more radically by placing its heroine in the midst of the Morant Bay Rebellion. The 1865 peasant rebellion resulted in cataclysmic government reprisals against the peasantry and the loss of representative government. It is a defining event in Jamaican literature as well as history. Small's story indicates that the early national conversation about Morant Bay included white middle-class women. Small's father was an Irish immigrant and her mother, the daughter of a Kingston solicitor. She later married a journalist, W.A. Stephenson and authored the novel, Undine in 1902 under the name Clarine Stephenson (Jamaica Times, 20 January 1912: 8).

Small's romance questions white creoles' allegiance to England and their refusal to ally themselves with Afro-Jamaicans. The hero is a Scottish soldier named Douglas, who is fighting with the British against the Jamaican peasant rebels. As the story begins, he sends his loyal servant Sam, a young black Jamaican, to fetch his Jamaican fiancée Clara for a final meeting. During the tryst, Douglas drops his marching orders, which Clara mistakes for a love letter. When she discovers her error, she rides through the night disguised in blackface and Sam's clothing to find Douglas. Just as the officer berates Douglas for losing the papers, the soldiers hear a rustling in the woods. They fear rebels. The officer asks Douglas to shoot. He refuses; the intruder may be a 'defenceless and perhaps innocent negro lad'. His commander retorts: 'Now Sir in the Queen's name fire or die'. Douglas obeys, arguing 'What after all is a black boy's life compared with her agony and heartbreak?' (Small, 1899: 13). He shoots, killing his hidden enemy, who turns out to be Clara dressed as an 'innocent negro lad'.

Both the tragedy in Small's story and the Jamaican tragedy of Morant Bay are pivoted on the invocation of Queen Victoria, mistaken identity and an exchange of letters. In 1865, broken by oppression and draught, Jamaican peasants 
petitioned the Queen for assistance in a letter. In place of material assistance, Queen Victoria sent a letter calling on Jamaicans to marry and to work industriously. She mistook an oppressed peasantry for lazy and depraved dependents. At the conclusion of the rebellion, the white elite forfeited the colony's representative government, in order to prevent Afro-Jamaicans from gaining political power. Small's story suggests that the tragedy might have been avoided had the white creole elite recognized the lives of Jamaican peasants as equal to their own and been willing to share political power with them. She does not imagine a resolution to the racial divide nor did the Jamaica Times, which continued the Queen's policy by telling the people to marry as a means of attaining progress. Small's tragic romance thus demonstrates both the radical political implications of early Jamaican nationalism and its profound limitations.

Women writers shaped Jamaican national literature in two further ways: they consistently challenged the stereotype of elite creole women, particularly white women, in British literature, and they subtly opened the category of elite heroines to include middle-class Afro-Jamaicans. Small's heroines are marked as white through references to blue eyes and white skin. Other writers such as Somerset present heroines with beautiful dark eyes and wavy hair. Many heroines are simply virtuous and attractive. The presence of dark beauties combined with the lack of specific reference to colour allows for a silent expansion of the category of lady to include the genteel women of the Afro-Jamaican middle classes.

However, even humble creole heroines like Dora required fundamentally revising the representation of creole women in British literature which, from the early eighteenth century onward, had defined them all - black, brown, and white - as 'antipodes' of respectable British womanhood. Rosabelle Joseph's 'An Exploded Theory', for instance, turns the tables on Jane Eyre's classic. In it, a Jamaican governess, not plain English Jane, becomes the beloved wife of a (Jamaican) gentleman. On learning that one of his 'Oxford Chums' has married a governess, James Merven exclaims that governesses are 'repellent' 'severe and uncompromising' (Joseph, 1900: 13). He later falls in love with a governess, the half-Jamaican Marjorie. Marjorie explodes the theory that governesses are repellent; Joseph explodes the theory that creoles are. Winn-Smith's 'The Legend of Edinboro Castle, St. Ann', also reworks the plot of Jane Eyre to vindicate white creole womanhood; it is the tale of a white Jamaican man who avenges the honour of his sister, Alicia Sutherland, whose beauty and innocence make her victim to a Scottish gentleman's seduction and abandonment (1899: 13).

The women writers of the Jamaica Times were not alone in redressing British stereotypes of creole women. In 1847, the creole Theodora Lynch presented her white creole heroine as a model of virtue in The Cotton Tree. Over a century later, 
Jean Rhys's Wide Sargasso Sea (1966) vindicated white creole womanhood on the international literary stage. White creole women have been historically viewed as guardians of the status quo from slavery to the class and colour hierarchy of colonial society. What is distinct about the women publishing in the Jamaica Times is that their rehabilitation of white creole womanhood contributed to a nationalist project that strove to transform the colonial status quo. This is a far cry from the 1970s when Kamau Brathwaite famously denied Rhys the status as a West Indian writer because she belonged to the white elite (1974: 38).

The prominence of Jamaican women writers was short lived. In 1903, MacDermot ended the short story contest in favour of a free standing series, the All Jamaica Library (1903-1909). With the publication of Herbert de Lisser's Jane's Career (1913), the genre 'yard fiction', centred on the daily lives of Kingston's urban poor, would become the quintessential Jamaican genre. But in 1903 the move away from the romance and the middle-class heroine was already clear. In the All Jamaica Library, three of four volumes featured the urban poor or peasantry, and the series included no women authors. Already in the Jamaica Times, nearly all short stories about black folk culture had been written by men. The imperative for folk aesthetics marginalized middle-class women because it required the author to claim a direct knowledge of the working class and peasantry. Too intimate a knowledge of folk culture placed respectable women at risk because their status depended on their distance from the supposed squalor, immorality and superstition of the working and peasant classes. ${ }^{5}$ Thus, the only woman to write stories that directly depict the folk was May Lopez, an expatriate (1902: 4; 1903: 3). The one exception proves the rule. In Small's short story 'Jambo's Story', an old peasant relates a tragic romance in Jamaican creole replete with folk beliefs (1898: 13). However, Small chose a British male tourist as her narrator, thus separating herself from her peasant subject. The price was high; she presents the peasantry through condescending, colonizing eyes.

\section{race and the middle-class woman writer}

Race was front and centre in the Jamaica Times' construction of national identity but like folk aesthetics, race was a taboo subject for women writers. Thus, 'The Dusky Strand' published under the patriotic pen name 'a Daughter of Jamaica', addresses the vital issue of Jamaica's African heritage without mentioning race. Returning to his home along the Rio Cobre, the enthusiastic father, James Raymond, throws his son, Lance, in the air; he fails to catch him, and the child falls to his death. Bereaved and aggrieved, his wife Violet separates from James, who suffers greatly because he has loved his child and wife intensely. He contemplates suicide, but the story ends happily when the wife returns with a new baby, born during their separation. The couple reconciles and thanks God for the
5 Jamaican women wrote poetry about the folk culture but this poetry invariably maintained the distance between the author and her subject; thus, Tropica (Mary Adella Wolcott) wrote with nostalgia of black servants in her 1904 collection The Island of Sunshine. 
brief life of their first child, a 'dusky strand'. He 'had seen fit to weave among the roseate hues of their lives - not to embitter and darken them - but to strengthen and beautify for evermore their "dear Love's tie", ('Daughter of Jamaica', 1902: 5). 'The Dusky Strand' is an allusion to Tennyson's poem, 'Maud'; in the short story, the phrase refers to the child's death. Yet the word cannot but introduce the matter of race because 'dusky' has been used so frequently in British writing on the Caribbean to refer to skin colour. Moreover, the author consistently uses terms that refer to colour to denote the relative happiness and success of the family. The 'dusky strand', for example, does not 'darken' but rather beautifies the 'roseate hues' of the family's life. At the turn of the century, Jamaica had a colour hierarchy that denied equal access to jobs and wealth to citizens with darker skin. Jamaica, was, in short, a country in which the relative happiness and success of a family often depended on its 'roseate' hue. It was also a country in which nearly all families, including the largely brownskinned middle class, had African ancestry. Thus this 'daughter of Jamaica' appears to be addressing the crux of Jamaican nationalism: how to include Jamaica's African heritage and its black folk in the national family. Her answer is unclear. Does the family's embrace of its dusky strand suggest that Jamaica embrace its African heritage and march proudly into a bright future, or does it suggest that this 'dark' heritage will be rendered invisible even as it contributes to a rose-coloured future?

The equivocal stance of the author reflects the contradictory racial politics of the respectable nationalism to which she contributed. The middle-class nationalists struggled against the colonial colour hierarchy by advocating that the middle class embrace (if ambivalently) its African heritage as the foundation for a national culture, but they also saw the peasantry as existing in a primitive space, separate from themselves. From the perspective of middleclass nationalists, the peasantry could participate in Jamaica's future modernity, only in so far as peasants assimilated respectably (Thomas, 2004: 13). Thus, I would argue, early Jamaican nationalists resembled the family of 'The Dusky Strand' with a slight modification: they embraced Jamaica's African heritage but sought to ensure that it would not darken the rose-tinted future.

At the turn of the century, the women writers of the Jamaica Times and Jamaica's black working classes occupied a similarly ambiguous position within nationalism. Both had symbolic prominence, as embodiments of modern morality and of national authenticity respectively. However, both were excluded from practical power. Women were denied economic independence as the movement never questioned legislation that prevented most married women from earning wages. The black peasant and working classes were denied leadership positions and social status on the grounds of their lack of education and morality. Moreover, the marginalization of middle-class women and these subaltern Jamaicans were tightly linked. Middle-class women's identity and privilege depended on their 
keeping themselves at a social and cultural distance from their subaltern compatriots. Thus paradoxically their parallel positions within nationalism placed an unbridgeable distance between middle-class women and subaltern Jamaicans. Una Marson explored this predicament two decades later in her play 'Pocomania' (1938). In it, her middle-class heroine, Stella Manners, must distance herself from the peasant religion Pukkumina, in order to marry and enter respectable womanhood. Marson also distanced herself also from the religion by omitting its less respectable elements from the play and rendering it very similar to mainstream Christianity (Rosenberg, 2007: 166-170). The class division continued to have serious consequences even for second-wave feminists. For instance, Honor Ford-Smith identified the 'lady bountiful' ideal as the key factor in dividing working and middle-class women in the Sistren Collective in the 1970s and 1980s and thus limiting the achievements of the Collective (Ford-Smith, 1997).

\section{conclusion}

It is important that literary and feminist historians take note of the women activists and writers documented in the Jamaica Times not only because their work illuminates the historical origins of class divisions in contemporary Jamaican feminism but also because they were significant contributors to early Jamaican nationalism and literature who expressed a feminist critique of that nationalism. Thus, I close by joining Evelyn 0'Callaghan in asking scholars to read early Caribbean women's writing. I add that we must read with an eye to historical context and in particular to the newspaper culture in which they published. It is only in this context that the winners of the Jamaica Times short story contest - unknown middle-class women from across Jamaica - can be understood as contributors to the formation of Jamaican nationalism and national literature, and as participating in the international movement of firstwave feminism, and its embrace by early nationalists in the colonized world. Outside this public sphere, the short stories of the Jamaica Times would likely be read as derivative of British literature and considered of little literary merit, which has been the fate of most early anglophone Caribbean literature. The women writers would be read as isolated, failed artists.

Studying and teaching such early work contributes to an important paradigm shift in Caribbean studies that expands our definitions of Jamaican nationalism and literature and, in so doing, promises to enrich feminist history. However, for this theoretical shift to occur, early Caribbean women's literature needs to be accessible. 0'Callaghan, Vassell, Gregg and a few others have done significant archival work, bringing out anthologies and reprints of early Caribbean women's writing (Vassell, 1993; Cassin, 2002; Gregg, 2005). But much remains to be done. The Jamaica Times, for instance, is difficult to get hold of. Other early works by 
6 The Jamaica Times is available in the British Library, the National Library of Jamaica, and the University of Rochester; issues from 1898 and 1899 appear to be only in the National Library of Jamaica. The Digital Library of the Caribbean (www.dloc.com) is undertaking the digitization of some early issues and the short stories.
Jamaican women such as Una Marson's plays and Stephenson's novel, Undine are equally scarce. ${ }^{6}$ However, digitization projects are now making it possible to have the access necessary for widespread scholarship and teaching of such texts, and it is for feminist scholars to ensure that early Caribbean women writers are not overlooked once again.

\section{author biography}

Leah Rosenberg (PhD Comparative Literature, Cornell, 2000) is Associate Professor of English at the University of Florida and author of Nationalism and the Formation of Caribbean Literature (Palgrave, 2007).

\section{references}

A Daughter of Jamaica (1902) 'The dusky strand' Jamaica Times, 8 February: 5.

Alexander, M.J. and Mohanty, C. (1997) editors, Feminist Genealogies, Colonial Legacies, Democratic Futures, New York: Routledge.

Altink, H. (2003) 'Respectability on trial: notions of womanhood in two Jamaican trials in the interwar years' in Courtman, S. (2003) editor, 'The society for Caribbean studies annual conference papers' Vol. 4, http://www.scsonline.freeserve.co.uk/olvol4.html.

Antrobus, P. and Sen, G. (2006) 'The personal is global: the project and politics of the transnational women's movement' in Batliwala, S. and Brown, L.D. (2006) editors, Transnational Civil Society: an Introduction, Bloomfield: Kumerian Press, 142-158.

Batliwala, S. and Brown, L.D. (2006) editors, Transnational Civil Society: An Introduction, Bloomfield: Kumerian Press.

Bhattachararya, B. (1980) Socio-Political Currents in Bengal: A Nineteenth Century Perspective, Sahibabad: Vikas publishing.

Brathwaite, K. (1974) Contradictory Omens, Kingston: Savacou.

Bryan, P. (1991) The Jamaican People 1880-1902, London: Macmillan Caribbean.

Burton, A. (1994) The Burdens of History: British Feminists, Indian Women, and Imperial Culture, 1865-1915, Chapel Hill: University of North Carolina Press.

Cassin, F. (2002) With Silent Tread: A West Indian Novel (1890), 0'Callaghan, E. (ed). Oxford: MacMillan Education Caribbean Classics.

Chatterjee, P. (1993) The Nation and its Fragments: Colonial and Postcolonial Histories, Princeton: Princeton University Press.

Cooper, F. and Stoler, A. (1997) editors, Tensions of Empire: Colonial Cultures in a Bourgeois World, Berkeley: University of California Press.

Cork, A. (1899) 'Such is life in the tropics' Jamaica Times, 7 January: 13.

Courtman, S. (2003) editor, 'The society for Caribbean studies annual conference papers' Vol. 4, http://www.scsonline. freeserve.co.uk/olvol4.html.

Cudjoe, S. (1990) editor, Caribbean Women Writers: Essays from the First International Conference, Amherst: University of Massachusetts Press.

Donnell, A. (2006) Twentieth-Century Caribbean Literature: Critical Moments in Anglophone Literary History, New York: Routledge.

Edmondson, B. (1999) Making Men: Gender, Literary Authority, and Women's Writing in Caribbean Narrative, Durham: Duke University Press. 
Ford-Smith, H. (1986) Una Marson: Black Nationalist, Kingston: Sistren Collection.

Ford-Smith, H. (1997) 'Ring ding ina tight corner: sistren, collective democracy, and the organization of cultural production' in Alexander, M.J. and Mohanty, C. (1997) editors, Feminist Genealogies, Colonial Legacies, Democratic Futures, New York: Routledge, 213-258.

French, J. and Ford-Smith, H. (1986) Women, Work and Organization in Jamaica 1900-1944, Kingston, Jamaica: Sistren.

Gregg, V. (2005) Caribbean Women: An Anthology of Non-Fiction Writing, 1890-1980, Notre Dame: University of Notre Dame Press.

Jarrett-Macaulay, D. (1998) The Life of Una Marson 1905-1965, Kingston: Ian Randle Publishers.

Jeffrey-Smith, U. (1899) 'Foiled' Jamaica Times, 28 January: 13.

Joseph, R. (1900) 'An exploded theory' Jamaica Times, 19 May: 13.

Lopez, M. (1902) 'A butday party' Jamaica Times, 11 January: 4.

Lopez, M. (1903) 'A Jamaica courtship' Jamaica Times, 3 January: 3.

Lynch, T. (1847) The Cotton Tree: Or Emily, the Little West Indian, a Tale for Young People, London: John Hatchard and Son.

Mathurin, L. (1975) The Rebel Woman in the British West Indies during Slavery, Illustrated by D Ranston, Kingston: Institute of Jamaica.

Mohammed, P. (1998) 'Rethinking Caribbean difference' Feminist Review, No. 59: 1-33.

O'Callaghan, ع. (2004) Women Writing the West Indies, 1804-1939: 'A Hot Place, Belonging to Us', New York: Routledge.

Paletschek, S. and Pietrow-Eunker, B. (2004) editors, Women's Emancipation Movements in the Nineteenth Century: A European Perspective, Stanford: Stanford University Press.

Reddock, R. (1988a) Elma Francois: The NWCSA and the Workers Struggle for Change in the Caribbean in the 1930's, London: New Beacon Books.

Reddock, R. (1988b) 'Feminism and feminist thought: an historical overview' in Shepherd, C. and Mohammed, P. (1988) editors, Gender in Caribbean Development, Jamaica: University of the West Indies Press, 53-73.

Reddock, R. (1990) 'Feminism, nationalism, and the early women's movement in the Englishspeaking Caribbean' in Cudjoe (1990) editors, Caribbean Women Writers: Essays from the First International Conference, Amherst: University of Massachusetts Press, 61-81.

Reddock, R. (1994) Women, Labour \& Politics in Trinidad \& Tobago: A History, Atlantic Highlands, N.J.: Zed Books.

Reid, V. (1949) New Day, New York: Alfred A Knopf.

Rendell, J. (2004) 'Recovering lost political cultures: British feminisms, 1860-1900' in Paletschek, S. and Pietrow-Eunker, B. (2004) editors, Women's Emancipation Movements in the Nineteenth Century: A European Perspective, Stanford: Stanford University Press, 33-52.

Rosenberg, L. (2007) Nationalism and the Formation of Caribbean Literature, New York: Palgrave MacMillan.

Shepherd, C. and Mohammed, P. (1988) editors, Gender in Caribbean Development, Jamaica: University of the West Indies Press.

Sherlock, P. and Bennett, H. (1998) The Story of the Jamaican People, Jamaica: Ian Randle Publishers.

Sinha, M. (1994) 'Mapping reading mother India: empire, nation, and the female voice' Journal of Women's History, Vol. 6, No. 2 (Summer): 6-44.

Sinha, M. (2000) 'The imperial social formation: a modest proposal for feminist history' Signs: Journal of Women in Culture and Society, Vol. 25, No. 4: 1077-1082.

Small, C. (1898) 'Jambo's story' Jamaica Times, 26 November: 13.

Small, C. (1899) 'In the queen's name' Jamaica Times, 1 April 1899: 13. 
Somerset, F.A. (1899) 'Two girls in the valley' Jamaica Times, 20 May: 13.

Thomas, D.A. (2004) Modern Blackness: Nationalism, Globalization, and the Politics of Culture in Jamaica, Durham: Duke University Press.

Tropica (Mary Adella Wolcott) (1904) Island of Sunshine, New York: Knickerbocker Press.

Vassell, L. (1993) editor, Voices of Women in Jamaica, Jamaica: Department of History, University of the West Indies.

Winn-Smith, W. (1898) 'A moonlight murder' Jamaica Times, 3 December: 13.

Winn-Smith, W. (1899) 'The legend of Edinboro castle, St. Ann' Jamaica Times, 4 February: 13.

doi: $10.1057 / f r .2009 .55$ 